\title{
Contribution to the knowledge of Camillea (Ascomycota, Graphostromataceae) in the Amazon forest in Pará, Brazil
}

\author{
Marcos Diones Ferreira SANTANA ${ }^{1 *}$, Douglas de Moraes COUCEIRO ${ }^{2}$, \\ Sheyla Regina Marques COUCEIRO ${ }^{1,3}$ \\ Universidade Federal do Oeste do Pará (UFOPA), Programa de Pós-Graduação em Biodiversidade e Biotecnologia (Bionorte), CEP 68040-470, Santarém, Pará, Brazil \\ 2 Universidade Federal do Oeste do Pará (UFOPA), Programa de Pós-Graduação em Biodiversidade (PPGBEES), CEP 68040-470, Santarém, Pará, Brazil \\ 3 Universidade Federal do Oeste do Pará (UFOPA), Laboratório de Ecologia e Taxonomia de Invertebrados Aquáticos (LETIA), CEP 68040-470, Santarém, Pará, Brazil \\ * Corresponding author: santana.mdf@gmail.com; (D) https://orcid.org/0000-0002-0421-3420
}

\begin{abstract}
Three species of the Ascomycetes genus Camillea were recorded in a fragment of Amazon rainforest in the region of Santarém, Pará state, Brazil. The occurrence of C. leprieurii, C. cyclops and C. bilabiata expand the range of distribution of these species in the state. Camillea leprieurii has previous records in the regions of Marabá, Oriximiná, Itaituba and Novo Progresso, while $C$. cyclops had been recorded in the west of the state. This is the first record of C. bilabiata for Pará. We provide a morphological description of the specimens and an identification key for Camillea species found in Pará.
\end{abstract}

KEYWORDS: Ascomycetes, Fungi, mycodiversity, Xylariales

\section{Contribuição ao conhecimento de Camillea (Ascomycota, Graphostromataceae) na floresta amazônica no Pará, Brasil}

\section{RESUMO}

Três espécies de Ascomycetes, gênero Camillea, foram registradas em um fragmento de floresta Amazônica na região de Santarém, Pará, Brasil. A ocorrência de C. leprieurii, C. cyclops e C. bilabiata expande a área de distribuição dessas espécies no estado. Camillea leprieurii foi registrada previamente nas regióes de Marabá, Oriximiná, Itaituba e Novo Progresso, enquanto C. cyclops havia sido registrada apenas no oeste do estado. Este é o primeiro registro de C. bilabiata no Pará. Fornecemos uma descrição morfológica dos espécimes e uma chave de identificação para as espécies de Camillea encontradas no Pará.

PALAVRAS-CHAVE: Ascomycetes, Fungi, micodiversidade, Xylariales

Of the 144,000 known species of fungi (Willis 2018), 5,719 have been described for Brazil, of which 1,881 species belong to the Ascomycota phylum (Maia et al. 2015). Camillea Fr. is a genus of Ascomycota that comprises 62 listed records, some as synonymys of species of Phylacia Lév. and Rhopalostroma D. Hawksw., with 46 recognized species in the Index Fungorum (CABI 2020), which formerly belonged to the Xylariaceae Tul \& C. Tul. family. Recently, Wendt et al. (2017) accommodated the genus in Graphostromataceae M.E. Barr, J.D. Rogers \& Y.M. Ju., which was accepted by Daranagama et al. (2018).

Camillea species generally have columnar (e.g. C. leprieurii (Mont.) Mont.), flattened (e.g. C. heterostoma (Mont.) Læssøe, J.D. Rogers \& Whalley) or discoid stroma (e.g. $C$. labellum Mont.), bipartite with dehiscent ectostromas, lightly colored and ornamented ascospores without visible germ slits (Læssøe et al. 1989; Hastrup and Læssøe 2009), although $C$. labiatirima J.D. Rogers, F. San Martín \& YM Ju has almost smooth ascospores with germ slits (Rogers et al. 2002). The genus is almost exclusively confined to the Americas and concentrated mainly in the Amazon region (Hastrup and Læssøe 2009).

The knowledge of the genus in the Brazilian Amazon, however, is based on only 14 species (Camillea amazonica Læssøe, J.D. Rogers \& Whalley; C. bilabiata Speg.; C. broomeana (Berk. \& M.A. Curtis) Læssøe, J.D. Rogers \& Whalley; C. cyclisca (Mont.) Læssøe, J.D. Rogers \& Whalley; C. cyclops (Mont.) Mont.; C. fossulata (Mont.) Læssøe, J.D. 
Rogers \& Whalley; C. fusiformis M.A. Whalley; C. labellum Mont.; C. leprieurii Mont.; C. macromphala (Mont.) Cooke; C. mucronata Mont.; C. patouillardii Læssøe, J.D. Rogers \& Whalley; C. tinctor (Berk.) Læssøe, J.D. Rogers \& Whalley and C. turbinata (Berk.) Speg. (CRIA 2020). In the state of Pará, the second largest state in Brazil, only C. leprieurii, $C$. mucronata and C. cyclops have been registered so far (Pereira 2015; Santana et al. 2018; CRIA 2020; Flora do Brasil 2020), evidencing the lack of data on fungal diversity in this region of great biological importance (Maia et al. 2015). Here we provide new occurrence records for Camillea species that expand their distribution in Pará. We include morphological descriptions and an identification key for Camillea species in Pará.

Camillea specimens were collected during excursions to fragments of Amazon rainforest near the Silvio Braga hydroelectric power plant (HPP) ( $2^{\circ} 48^{\prime} 44.45^{\prime \prime} \mathrm{S}$, $\left.54^{\circ} 17^{\prime} 56.23^{\prime \prime} \mathrm{W}\right)$ in western Pará state, Brazil, in November 2017 and April and July 2018. The fragments present around 30,000 ha each, and for the most part, they are in a plateau area with little variation (Silva 1966), covered with highcanopy forest, understory dominated by natural regeneration, herbaceous and shrub plants, palm trees and bushes.

The primary vegetation cover in the region is dense ombrophilous forest (Veloso et al. 1991). The climate is xeroquimenic (Bagnouls and Gaussen 1963), with an average temperature of $27^{\circ} \mathrm{C}\left( \pm 5^{\circ} \mathrm{C}\right)$ and average relative humidity of about $88 \%$. The average annual rainfall is $2,200 \mathrm{~mm}$, with a rainy season from January to May (monthly average of 231 $\mathrm{mm}$ ) and a dry season from June to December (monthly average of $61 \mathrm{~mm}$ ) (Alvares et al. 2013).

Fungal specimens were removed from the substrate with the help of a pocket knife and placed in paper bags as proposed by Lodge et al. (2004). They were dehydrated at 38 ${ }^{\circ} \mathrm{C}$ for 48 hours, for taxonomic identification. Macroscopic stroma characteristics were observed as described by Læssøe et al. (1989), San Martin González and Rogers (1993), Whalley (1995) and Hastrup and Læssøe (2009). Microscopic characteristics were not observed, but the species were easily identified in the field (Hastrup and Læssøe 2009). Reference samples were deposited in the fungi collection of the HSTM herbarium of Universidade Federal do Oeste do Pará (UFOPA).

We collected 15 Camillea specimens belonging to three species: C. bilabiata (HSTM-Fungi 12288; 12284; 12281; 12277; 12279; 12286), C. cyclops (HSTM-Fungi 10799; $12285 ; 12283 ; 12282 ; 12280 ; 12278 ; 12276)$ and C. leprieurii (HSTM-Fungi 12290; 12287). The fungi were found on trunks and branches of fallen trees with rigid decomposition, a habitat that coincides with what is known from other species of the family (Læssøe et al. 1989; Whalley 1996; Pereira 2011;2015).
In Pará, C. leprieurii is the most representative species, occurring in the regions of Marabá, Oriximiná, Itaituba and Novo Progresso. Camillea mucronta and C. cyclops were recorded only in the western region of the state (Santana $e t$ al. 2018; CRIA 2020). This study reports C. bilabiata as a new record for the state of Pará (Figure 1). The material in this study agrees with the description of Hastrup and Læssøe (2009) and Pereira (2011). Silveira and Rodrigues (1985) began their studies in the Amazon, with specimens from the states of Amazonas and Mato Grosso, reporting five species of Camillea, among which C. bilabiata, C. cyclops and C. leprieurii were listed, in addition to $C$ bacillum and C. labellum.

\section{Taxonomy}

Camillea cyclops (Mont.) Mont., Annales des Sciences Naturelles Botanique 3: 113 (1855). Figure 2a-e.

Hypoxylon cyclops Mont., Annales des Sciences Naturelles Botanique 13: 353 (1840).

Eroded cylindrical stroma with $3-5 \mathrm{~mm}$ in diameter, with a flat apical, circular disk surrounded by a ring below, carbonaceous and black, each containing 6-8 perithecia located in its central region. Papillary ostioles emerge in a ring below the apical disc. Ascus and ascospores not seen. The examined specimens are similar to those examined by Læssøe et al. (1989).

Material examined - Brazil, Pará, Santarém, forest fragment near Silvio Braga HPP (Curuá-Una hydroelectric power plant), on a decaying fallen trunk, $02^{\circ} 48^{\prime} 55.8^{\prime \prime} S$, 0541'ㄷ‥'”, 20 XI 2017, Santana, MDF 457, HSTMFungi 12276; on a decaying trunk, $02^{\circ} 48^{\prime} 49.45^{\prime \prime S}$, 541'04.3"W, 20 VII 2017, Santana, MDF-508, HSTMFungi 12278; on a decaying fallen trunk, $2^{\circ} 48^{\prime} 49.45^{\prime \prime}$ S, $54^{\circ}$

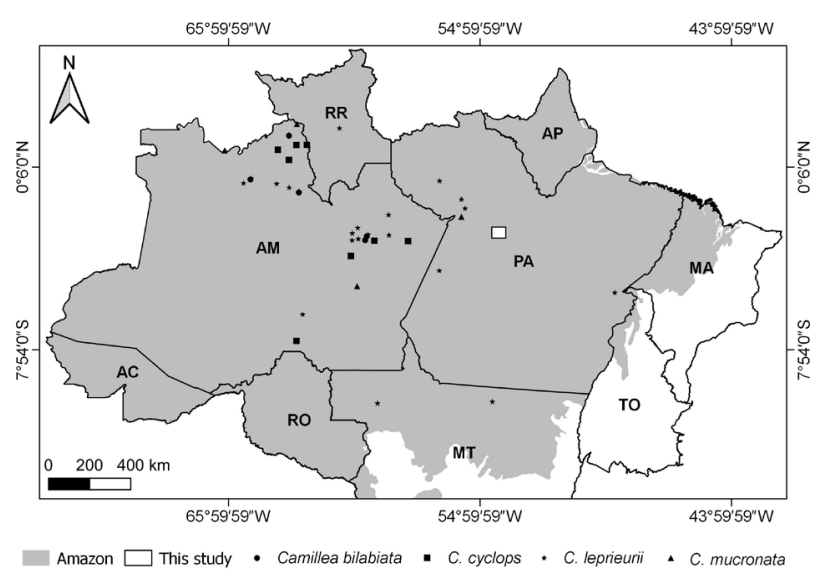

Figure 1. Distribution of Camillea species in the Brazilian Amazon region (area in grey). Letters are the acronyms for state names. $A C=A c r e ; A M=$ Amazonas; $\mathrm{AP}=$ Amapá; $\mathrm{MA}=$ Maranhão; $\mathrm{MT}=$ Mato Grosso; $\mathrm{PA}=$ Pará; $\mathrm{RO}=$ Rondônia; $\mathrm{RR}$ $=$ Roraima; $\mathrm{TO}=$ Tocantins. 

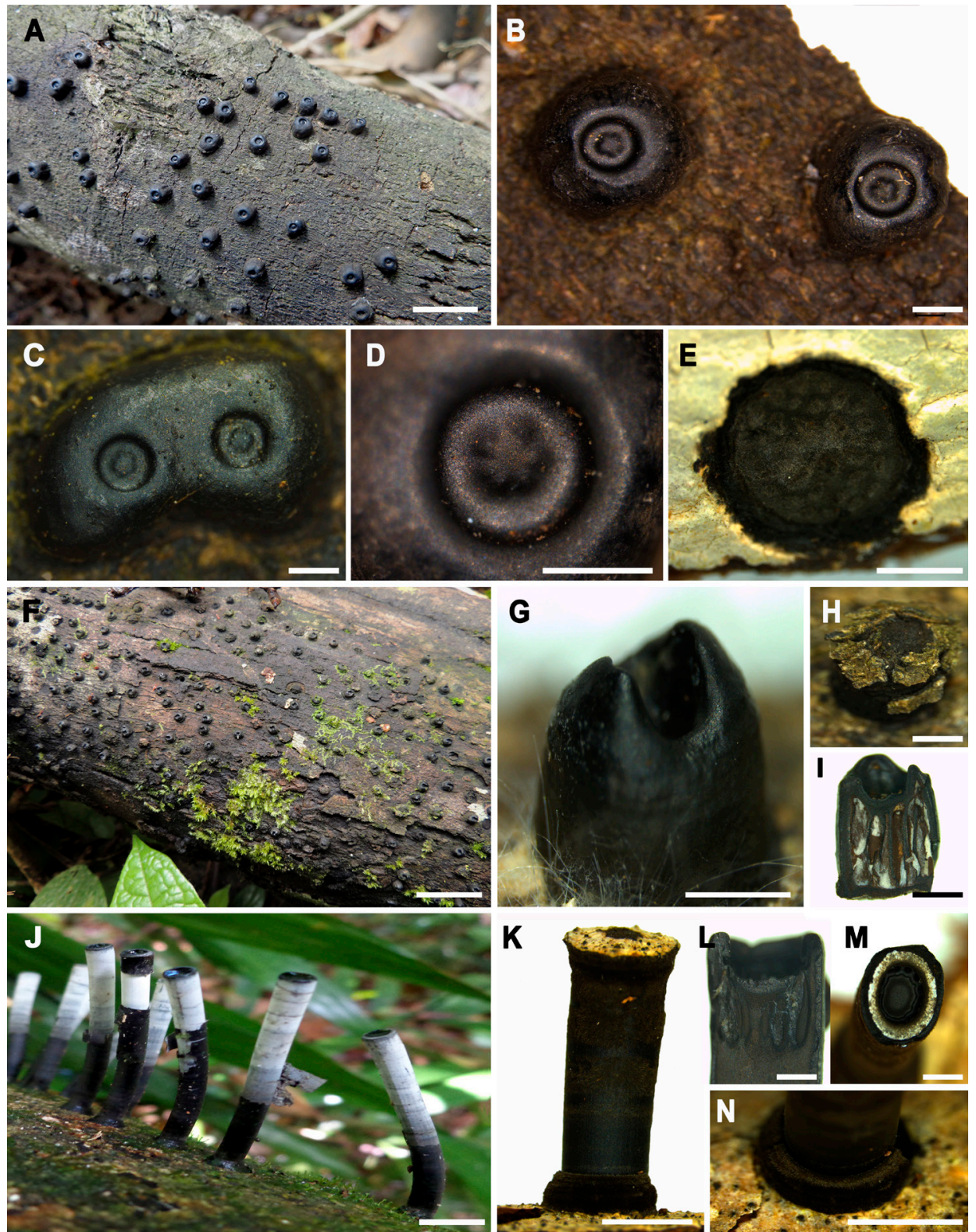

Figure 2. Camillea species recorded in the Santarém region, western Pará state, Brazil. A-E - C. cyclops [A - gregarious stromata; B - stromata; C - fused stromata; D - ostiolar region of the stromal disc; $\mathrm{E}$ - upper part of the stromata removed to reveal the region of perithecia]; F-I - C. bilabiata [F - gregarious stromata; G - bilabial apex do stromata; $\mathrm{H}$ - juvenile stroma with remains of adhered substrate; I - cross section showing perithecia]. J-N - C. leprieurii [J - gregarious stromata; $\mathrm{K}$ - juvenile stroma; L - cross section showing perithecia; $\mathrm{M}$ - discoid apex with depression; $\mathrm{N}$ - basal disc slightly wider at the base]. Scale bars: A, F, J = $1 \mathrm{~cm} ; \mathrm{B}, \mathrm{C}, \mathrm{E}, \mathrm{G}-\mathrm{I}, \mathrm{K}-\mathrm{N}=$ $1,5 \mathrm{~mm} ; \mathrm{D}=1 \mathrm{~mm}$. This figure is in color in the electronic version.

17’04.3”W, 29 IV 2018, Santana, MDF 617, HSTM-Fungi 12282.

Camillea bilabiata Speg., Boletín de la Academia Nacional de Ciencias en Córdoba 11 (4): 509-510 [no. 259, reprint pages 131-132], 1889. Figure 2f-i.

Numulariola bilabiata (Speg.) PMD. Martin, South African Journal of Botany 35: 288, 1969.

Eroded, erect, with 3-5 $\mathrm{mm}$ in diameter, with concave surface and bilabial apex, brownish black, glabrous stromata, gregarious. Carbonaceous, brittle perithecia form long individual channels that merge into a common channel just below the ostiole. The characteristics of the examined specimens are similar to the descriptions by Læssøe et al. (1989) and Hastrup and Læssøe (2009).

Material examined - Brazil, Pará, Santarém, forest fragment near the Silvio Pinto HPP (Curuá-Una hydroelectric power plant), on a tree branch on the ground, $2^{\circ} 48^{\prime} 38.0^{\prime \prime} \mathrm{S}$, 54²17'22.0”W, 27 IV 2018, Santana, MDF 487, HSTM- 
Fungi 12277; on a decaying fallen trunk on the ground, 2'48'25.1”S, 54¹8'22.8”W, 27 IV 2018, Santana, MDF 584, HSTM-Fungi 12284; on a dead tree on the ground, 248'02.7”S, 54¹8'19.7”W, 29 IV 2018, Santana, MDF 622, HSTM-Fungi 12288.

Camillea leprieurii (Mont.) Mont., Annales des Sciences Naturelles Botanique 3: 112 (1855). Figure 2j-n.

Hypoxylon leprieurii Mont., Annales des Sciences Naturelles Botanique 13: 352 (1840).

Eroded, squamous white, cylindrical stromata, with $2.5-3 \mathrm{~mm}$ in diameter and $15-20 \mathrm{~mm}$ high, attached to the substrate after the upper part was broken off, with discoid apex up to $1 \mathrm{~mm}$ deep, with rounded and narrow margin. Elongated, ovoid perithecia with individual ostioles. Ostioles along the margin of the depression, individually eroded into annular and papillary depressions. The characteristics of the examined specimens are similar to the description by Læssøe et al. (1989).

Material examined - Brazil, Pará, Santarém, forest fragment near the Silvio Pinto HPP (Curuá-Una hydroelectric power plant), $02^{\circ} 48^{\prime} 30.8^{\prime} \mathrm{S}, 054^{\circ} 17^{\prime} 25.1^{\prime \prime W}$, on a decaying fallen trunk on the ground with rigid composition, 29 IV 2018, Santana, MDF 621, HSTM 12287; on a branch on the ground, 248'49.4”S, 54¹7’03.9”W, 30 VII 2018, Santana, MDF 636, HSTM-Fungi 12290.

\section{Key to Camillea species occurring in Pará state (Brazil)}

1. Stromata cylindrical or discoid 2

1'. Stromata tube-shaped with wider basal disc ..... C. leprieurii 2. Stromata with an apical circular depression ... 3

2'. Stromata with concave bilabial apex C. bilabiata

3. Stromata with a tapered stylus sticking out of the apical depression C. mucronata

3'. Stromata without stylus within the apical depression C. cyclops

Xylariales are uncertain due to the lack of molecular data, as well as overlapping morphological characteristics (Daranagama et al. 2018), which is why Camillea is rarely addressed in scientific studies. In addition, the fragile material is rarely in good condition to obtain cultures and allow sequencing, which is reflected in the limited number of accessions from this genus in GenBank/NCBI. Of 27 deposited sequences for Camillea, only one is from a species recorded in this study (Camillea cyclops, with a registered sequence \# MF038958.1; NCBI 2020).

In Brazil, including this study, there are 162 records of C. leprieurii, 32 of C. bilabiata, 42 of C. cyclops and 16 of C. mucronata (CRIA 2020; Flora do Brasil 2020). These numbers, as well as the diversity of Graphostromataceae, are expected to be higher, especially in the Amazon, that harbors great mycological diversity (Hawksworth 2001), but where the scarce number of professionals and difficult access to isolated areas are obstacles to large-scale fungal surveys.

\section{ACKNOWLEDGMENTS}

The authors thank Pró-reitoria de Pesquisa, Pós-graduação e Inovação Tecnológica (PROPPIT) of Universidade Federal do Oeste do Pará (UFOPA), for the logistical support, especially for field trips.

\section{REFERENCES}

Alvares, C.A.; Stape, J.L.; Sentelhas, P.C.; Gonçalves, J.L.M.; Sparovek, G. 2013. Köppen's climate classification map for Brazil. Meteorologische Zeitschrift, 22: 711-728.

Bagnouls, F.; Gaussen, H. 1963. Os climas biológicos e sua classificação. Boletim de Geografia, 22: 545-566.

CABI Bioscience. 2020. The CABI Bioscience and CBS Database of Fungal Names. (http://www.indexfungorum.org/Names/Names. asp). Accessed on 02 Jul 2020.

CRIA. 2020. Species Link. (http://splink.cria.org.br). Accessed on $01 \mathrm{Jul} 2020$.

Daranagama, D.A.; Hyde, K.D.; Sir, E.B.; Thambugala, K.M.; Tian, Q.; Samarakoon, M.C. et al. 2018. Towards a natural classification and backbone tree for Graphostromataceae, Hypoxylaceae, Lopadostomataceae and Xylariaceae. Fungal Diversity, 88: 1-165.

Flora do Brasil 2020 em construção. 2020. Jardim Botânico do Rio de Janeiro. (http://floradobrasil.jbrj.gov.br). Accessed on 01 July 2020.

Hastrup, A.C.S.; Læssøe, T. 2009. Camillea (Xylariaceae, Ascomycota), including two new species, along a trans-Andean altitude gradient in Ecuador. Mycological Progress, 8: 305-316.

Læssøe, T.; Rogers, J.D.; Whalley, A.S. 1989. Camillea, Jongiella and light-spored species of Hypoxylon. Mycological Research, 93: 121-155.

Lodge, D.J.; Ammirati, J.F.; O’Dell, T.E.; Mueller, G.M. 2004. Collecting and describing macrofungi. In: Mueller, G.M.; Bills, G.F.; Foster, M.S. (Ed.). Biodiversity of Fungi: Inventory and Monitoring Methods. Elsevier Academic Press, Oxford, 777p.

Maia, L.C.; Júnior, A.A.C.; Cavalcanti, L.H.; Gugliotta, A.M.; Drechsler-Santos, E.R.; Santiago, A.L.M.A.; et al. 2015. Diversity of Brazilian Fungi. Rodriguésia, 66: 1033-1045.

NCBI. 2020. GenBank. (https://www.ncbi.nlm.nih.gov/genbank/). Accessed on 13 May 2020.

Pereira, J. 2011. Xylariaceae (Ascomycota) em áreas de Mata Atlântica nordestina e em herbários brasileiros. Doctoral thesis, Universidade Federal de Pernambuco, Brazil. 223p. (https://repositorio.ufpe. br/handle/123456789/751)

Pereira, J. 2015. Xylariales in Lista de Espécies da Flora do Brasil. Jardim Botânico do Rio de Janeiro. (http://floradobrasil.jbrj.gov. br/jabot/floradobrasil/FB121088). Accessed on 25 Mar 2018. 
Rogers, J.D.; San Martín Gonzales, F.; Ju, Y.M. 2002. Three new taxa of Camillea from Costa Rica. Sydowia, 54: 84-90.

San Martín González, F.; Rogers, J.D. 1993. Biscogniauxia and Camillea in Mexico. Mycotaxon, 47: 229-258.

Santana, M.D.F.; Couceiro, D.M.; Couceiro, S.R.M. 2018. Macrofungi of the Floresta Nacional do Tapajós. (https:// fieldguides.fieldmuseum.org/pt-br/guias/guia/996). Accessed on 10 May 2020.

Silveira, V.D.; Rodrigues, K.F. 1985. Levantamento preliminar de Xylariaceae da Amazônia. Acta Amazonica, 15: 7-27.

Veloso, H.P.; Rangel Filho, A.L.R.; Lima, J.C.A. 1991. Classificação da Vegetação Brasileira Adaptada a um Sistema Universal. IBGE, Rio de Janeiro, 124p.

Wendt. L.; Sir, E.B.; Kuhnert, E.; Heitkämper, S.; Lambert, C.; Hladki, A.I.; et al. 2017. Resurrection and emendation of the
Hypoxylaceae, recognised from a multigene genealogy of the Xylariales. Mycological Progress, 17: 115-154.

Whalley, M.A. 1995. Camillea fusiformis sp. nov. from Ecuador. Sydowia, 47: 82-88.

Whalley, M.A. 1996. Distinctive features of Camillea (Xylariaceae) from Cuyabeno as revealed by scanning electron microscopy. Mycologist, 10: 149-151.

Willis, K. J. (Ed.). 2018. State of the World's Fungi 2018. Report. Royal Botanic Gardens, Kew, 92p.

RECEIVED: $21 / 08 / 2019$

ACCEPTED: $24 / 07 / 2020$

ASSOCIATE EDITOR: Nelson Menolli Junior 